\title{
The virgin population of Neisseria gonorrhoeae in Stockholm has decreased and antimicrobial resistance is increasing
}

\author{
M Bäckman, K Jacobson, S Ringertz
}

\begin{abstract}
Aims-To investigate the evolution of chromosomal and plasmid mediated resistance for ampicillin and tetracycline of $\boldsymbol{N}$ gonorrhoeae strains in Stockholm during 1982-1993.

Methods-A total of 404 gonococcal strains isolated in 1982, 1987, 1990, 1992, 1993 were analysed for minimal inhibitory concentrations (MIC) of ampicillin and tetracycline and for plasmid content. MIC values were determined by the agar dilution method and plasmid preparations were performed using alkaline lysis. To detect additional gonococcal strains with tet(M) plasmids all strains isolated in 1988-1989 and 1991, in all 234 isolates, were analysed retrospectively for MIC values of tetracycline. If an MIC value of $\geqslant 4.0 \mathrm{mg} / \mathrm{l}$ was recorded plasmid analysis was performed.

Results-Increased proportions of chromosomally mediated resistance to tetracycline $(p<0.001)$ as well as plasmid mediated resistance to both ampicillin (p $<0.02$ ) and tetracycline were found in the later part of the study. In 1991 the first gonococcus with tet(M) plasmid was isolated in Sweden. The proportion of strains with chromosomally mediated resistance for ampicillin did not change during the study period. The proportion of gonococcal strains with the $39 \mathrm{~kb}$ conjugative plasmid was increased in the later part of the study.
\end{abstract}

Conclusions-The increased proportion of $\boldsymbol{N}$ gonorrhoeae strains with resistance to ampicillin and tetracycline is most likely due to importation of strains from areas with high prevalence of antibiotic resistant gonococci. The proportion of $N$ gonorrhoeae strains with tet(M) plasmids is low in Sweden, but might increase in the same way as the proportion of PPNG strains has increased during 1982-1993.

(Genitourin Med 1995;71:234-238)

Keywords: Neisseria gonorrhoeae; antibiotic resistance; plasmid

\section{Introduction}

There are two major mechanisms of penicillin and tetracycline antimicrobial resistance in Neisseria gonorrhoeae, chromosomally encoded and plasmid mediated resistance. Chromosomal resistance is encoded by several loci with additive effects ${ }^{1}$ and is due to alterations in the penicillin binding proteins and reduced permeability of the outer membrane (for review see ${ }^{2}$ ). This leads to various degrees of reduced susceptibility to tetracycline and beta-lactam antibiotics. Gonococcal strains with stepwise reduced susceptibility to penicillin were reported already in $1946 . .^{3}$ Before beta-lactam antibiotics became commonly used in the 1950 s the MIC values of the virgin gonococci were $<0.1 \mathrm{mg} / 1$ for penicillin. ${ }^{1}$ Plasmid mediated resistance to penicillin in gonococci caused by the production of penicillinase (beta-lactamase) was reported in early 1976.45 These penicillinase producing $N$ gonorrhoeae (PPNG) strains spread rapidly over the world. ${ }^{6}$ The first PPNG strain was reported in Sweden in September $1976 .{ }^{7}$ PPNG strains produce a TEM-1 type betalactamase which hydrolyses the beta-lactamring. ${ }^{8}$ The PPNG strains mostly carry a beta-lactamase encoding plasmid of African $(5 \cdot 1 \mathrm{~kb})$ or Asian $(7 \cdot 2 \mathrm{~kb})$ type, but other beta-lactamase encoding plasmids have also been reported (for review see ${ }^{9}$ ). The chromosomally encoded tetracycline resistance is mediated through three different mechanisms; energy dependent efflux of tetracycline, ribosomal protection by reduced binding of tetracycline to the bacterial ribosom, and chemical alteration of the tetracycline molecule (for review see ${ }^{10}$ ). Resistance to tetracycline was not found when Danish strains from 1944 and 1957 were analysed. ${ }^{11}$ Plasmid mediated resistance to tetracycline was first reported in $1985 .{ }^{12}$ It was introduced through a conjugative plasmid which carried a tet $(\mathbf{M})$ determinant. ${ }^{13}$ It encodes for a protein which appears to protect the translation apparatus in an as yet undefined way. ${ }^{14} \operatorname{Tet}(\mathrm{M})$ containing strains have been reported from different parts of the world. ${ }^{9}$ Two types of this plasmid have been found; the American (42 $\mathrm{kb})$ and the Dutch $(40 \mathrm{~kb}) .{ }^{15}$ It has been suggested that they have different origins. ${ }^{16}$ The tet $(\mathrm{M})$ plasmid is also able to conjugate betalactamase plasmids. ${ }^{17}$ Plasmid mediated resistance to ampicillin and tetracycline is generally at a higher level than chromosomally mediated resistance. This study was conducted to investigate the evolution of chromosomal and plasmid mediated resistance to ampicillin and tetracycline in $N$ gonorrhoeae strains in Stockholm during 1982-1993. 
Materials and methods

Patients and gonococcal strains

Samples from patients attending out-patient clinics both at two general hospitals and from general practitioners rooms in the southern parts of the Stockholm area were included. The catchment area was the same during the study. The proportion of women decreased in the later part of the study and the arithmetic mean of the age increased for both women and men. The proportion of patients with gonorrhoea from STD clinics varied in the beginning of the study, reflecting different strategies of healthcare during that period. In 1982 the proportions of patients from a STD clinic were $78 \%$ compared with $35 \%$ in 1987 . During the later part of the study the proportions of patients from a STD clinic were more stable, in $199053 \%$, in $199261 \%$ and in $199356 \%$. The proportions of patients from primary health care centres were $7 \%$ in 1982 and $30-40 \%$ during the rest of the study. Suspected gonococcal strains were isolated on the basis of colony morphology and positive oxidase test. They were verified by Gram stain and in 1982 fermentation of carbohydrates were included in all verifications. In 1987-1993 co-agglutination (Phadebact, Boule Diagnostics AB, Huddinge, Sweden) was used instead, with the addition of fermentation of carbohydrates if the coagglutination test was negative. All strains included were positive in the coagglutination test. All gonococcal strains in the study were either consecutive or selected randomly from consecutively collected strains by a computer program for randomisation. If more than one strain with the same serovar were isolated from a patient within six weeks only one was included. A total of 404 strains from five different time periods were analysed for MIC values of ampicillin and tetracycline and for plasmid content (table 1). In order to detect tet(M) plasmid containing $N$ gonorrhoeae strains all strains isolated from July 1988-February 1990 (174 strains) and from March 1991-February 1992 (60 strains) were analysed retrospectively for MIC values of tetracycline. If more than one strain with the same serovar were isolated from a patient within six weeks only one was included. If the strain had a recorded MIC value of $\geqslant 4 \mathrm{mg} / 1$ for tetracycline plasmid analysis was performed.

Table 1 Neisseria gonorrhoeae strains analysed for minimal inhibitory concentrations of ampicillin and tetracycline and for plasmid content

\begin{tabular}{lll}
\hline & $\begin{array}{l}\text { No of strains } \\
\text { selected/ } \\
\text { No of strains } \\
\text { isolated }\end{array}$ & $\begin{array}{l}\text { Referred } \\
\text { to as }\end{array}$ \\
$\begin{array}{l}\text { Timeperiod } \\
\text { of isolation }\end{array}$ & $106 / 905$ & 1982 \\
\hline $\begin{array}{l}\text { March 1982- } \\
\begin{array}{l}\text { Feb 1983 } \\
\text { June 1987- }\end{array}\end{array}$ & $104 / 189$ & 1987 \\
$\begin{array}{l}\text { May 1988 } \\
\text { March 1990- }\end{array}$ & $99 / 99$ & 1990 \\
$\begin{array}{l}\text { Feb 1991 } \\
\text { March 1992- }\end{array}$ & $56 / 56$ & 1992 \\
$\begin{array}{l}\text { Feb 1993 } \\
\text { March 1993- } \\
\text { Feb 1994 }\end{array}$ & $39 / 39$ & 1993 \\
\hline
\end{tabular}

${ }^{\star}$ If more than one strain with the same serovar were isolated from a patient within six weeks only one was included.
Minimum inhibitory concentrations

The MIC values were determined by the agar dilution method on GC agar base II (BBL, Cockeysville, Maryland, USA) with $1 \%$ IsoVitaleX (BBL) and $40 \mathrm{mg} / \mathrm{l}$ of haemin (Sigma) ${ }^{18}$ containing two-fold dilutions of each antibiotic. Ampicillin sodium (Astra AB, Södertälje, Sweden) and tetracycline hydrochloride (Pharmacia AB, Stockholm, Sweden) were used at concentrations of 0.03-128 mg/l. Ampicillin and not penicillin was chosen since the former was the drug of choice in Sweden. The MIC50 and MIC90 values for penicillin and ampicillin do not differ more than one dilution step. ${ }^{18}$ All MIC determinations were carried out in duplicate. The mean of the MIC values was calculated for each strain and if it was in between two dilution steps it was adjusted to the nearer higher MIC value. All gonococcal strains had been stored in $-70^{\circ} \mathrm{C}$. A total of twenty strains did not grow, these strains did belong to different serovars and did not have any obvious characteristics in common. For MIC determination 100 gonococcal strains were tested together. As controls five gonococcal strains, WHO A, WHO B, WHO C, WHO D and WHO $\mathrm{E}$ were used. All isolates having a MIC to ampicillin of $\geqslant 2 \mathrm{mg} / \mathrm{l}$ were tested for penicillinase production using chromogenic cephalosporin substrate; Nitrocefin disc test (AB Biodisk, Solna, Sweden). Strains negative in the Nitrocefin test with a MIC value of $\geqslant 2.0 \mathrm{mg} / 1$ were defined as having chromosomally mediated resistance to ampicillin (CMRA). Strains positive in the Nitrocefin test were regarded as PPNG. All strains carrying a plasmid of $38-42 \mathrm{~kb}$ were analysed for the tet(M) plasmid (see below). All isolates without a tet $(\mathrm{M})$ carrying plasmid but with a MIC value $\geqslant 2.0 \mathrm{mg} / 1$ to tetracycline were regarded as having chromosomally mediated resistance to tetracycline (CMRT).

Plasmid DNA preparation, agarose gel electrophoresis and restriction endonuclease digestion For the plasmid isolation cells from one haematin agar plate, incubated for 18-24 h, were scraped off with cotton wool swabs and suspended in $2.5 \mathrm{ml} 50 \mathrm{mM}$ glucose in TE $(25 \mathrm{mM}$ Tris. $\mathrm{Cl}$ and $10 \mathrm{mM}$ EDTA, $\mathrm{pH}$ 8.0). The cells were harvested and plasmid DNA isolation was performed using alkaline lysis. ${ }^{19}$ For the agarose gel electrophoresis $3 \mu \mathrm{l}$ of plasmid DNA were mixed with $7 \mu \mathrm{l}$ TE and $2 \mu \mathrm{l}$ of loading buffer $(0.25 \%$ bromphenol blue, $0.25 \%$ xylene cyanol, $40 \%$ sucrose). The electrophoresis (Miniphor Electrophoresis, LKB, Stockholm, Sweden) was performed on $0.8 \%$ agarose gel (Seakem, ME, FMC, Invitro, Solna, Sweden) with $0.5 \mu \mathrm{g} / \mathrm{ml}$ ethidium bromide at approximately $8 \mathrm{~V} / \mathrm{cm}$ for $2.5 \mathrm{~h}$ in TBE ( $89 \mathrm{mM}$ Tris base, $89 \mathrm{mM}$ boric acid, $2.0 \mathrm{mM}$ EDTA, pH 8.0). The bands were detected on an UV table and photographed. Five gonococcal strains with known plasmids; CCUG 5449, CCUG 6395, CCUG 32095, CCUG 32096 (Culture Collection, University of Gothenburg, Dep of Clin Bact, S-413 46 Gothenburg, Sweden) 
Table 2 Distribution of minimal inhibitory concentrations of ampicillin and tetracycline in $N$ gonorrhoeae strains isolated at Stockholm Söder Hospital, Sweden

\begin{tabular}{|c|c|c|c|c|c|c|c|c|c|}
\hline & \multicolumn{5}{|c|}{ Minimal inhibitory concentrations of ampicillin * } & \multicolumn{4}{|c|}{ Minimal inhibitory concentrations of tetracyclin } \\
\hline & $\underset{N o}{\leqslant 0.06}$ & $\begin{array}{l}0.12-0.25 \\
\text { No }\end{array}$ & $\begin{array}{l}0 \cdot 5-1 \cdot 0 \\
\text { No }\end{array}$ & $\begin{array}{l}\geqslant 2 \cdot 0 \\
\text { CMRA† } \\
\text { No }\end{array}$ & $\begin{array}{l}>2 \cdot 0 \\
\text { betał } \\
\text { No }\end{array}$ & $\begin{array}{l}0.12-0.25 \\
\text { No }\end{array}$ & $\begin{array}{l}0 \cdot 5-1 \cdot 0 \\
\text { No }\end{array}$ & $\begin{array}{l}\geqslant 2 \cdot 0 \\
C M R T S \\
\text { No }\end{array}$ & $\begin{array}{l}\geqslant 2 \cdot 0 \\
\operatorname{tet}(M) \\
\text { No }\end{array}$ \\
\hline \multirow{5}{*}{$\begin{array}{l}1982 \\
n=106 \\
1987 \\
n=104 \\
1990 \\
n=99 \\
1992 \\
n=56 \\
1993 \\
n=39\end{array}$} & 14 & 33 & 51 & 6 & 2 & 38 & 50 & 18 & 0 \\
\hline & 22 & 33 & 35 & 8 & 6 & 27 & 54 & 23 & 0 \\
\hline & 33 & 21 & 31 & 5 & 9 & 11 & 47 & 41 & 0 \\
\hline & $\mathbf{0}$ & 23 & 18 & 4 & 11 & 11 & 26 & 18 & 1 \\
\hline & 10 & 5 & 17 & 2 & 5 & 4 & 12 & 20 & 3 \\
\hline
\end{tabular}

ᄎ in mg/l.

$+N$ gonorrhoeae strains with chromosomally mediated resistance to ampicillin.

$¥ N$ gonorrhoeae strains with beta-lactamase plasmid.

$\boldsymbol{N}$ gonorrhoeae strains with chromosomally mediated resistance to tetracycline.

II $N$ gonorrhoeae strains with tet(M) plasmid.

and $E$ coli $\mathrm{V} 512^{20}$ served as controls. Isolates with plasmid bands around 38-42 kb were digested with the restriction endonuclease Bgl I (Boehringer Mannheim, Biochemica, Germany) according to the manufacturers instructions. The digested DNA was separated on $0.8 \%$ agarose gel with $0.5 \mu \mathrm{g} / \mathrm{ml}$ ethidium bromide.

\section{Serological classification}

All strains were classified with monoclonal antibodies of the Pharmacia-panel (Boule Diagnostics AB, Huddinge, Sweden). The monoclonal antibodies used for detecting Protein IA were Ar, Ao, As, At, Av and for Protein IB: $\mathrm{Br}, \mathrm{Bo}, \mathrm{Bp}, \mathrm{By}, \mathrm{Bv}, \mathrm{Bu}, \mathrm{Bs}, \mathrm{Bt}$, $B x$. The WI strains were labelled with an "A" (PrIA) and the WIIIII strains with a " $B$ " (PrIB) followed by small letters according to their reactions with the different monoclonal antibody reagents. The antigens were prepared as described. ${ }^{21}$ Co-agglutination was performed on bioplates (LabDesign AB, Täby, Sweden).

\section{Statistical analysis}

Fisher's exact test and the chi square test were used.

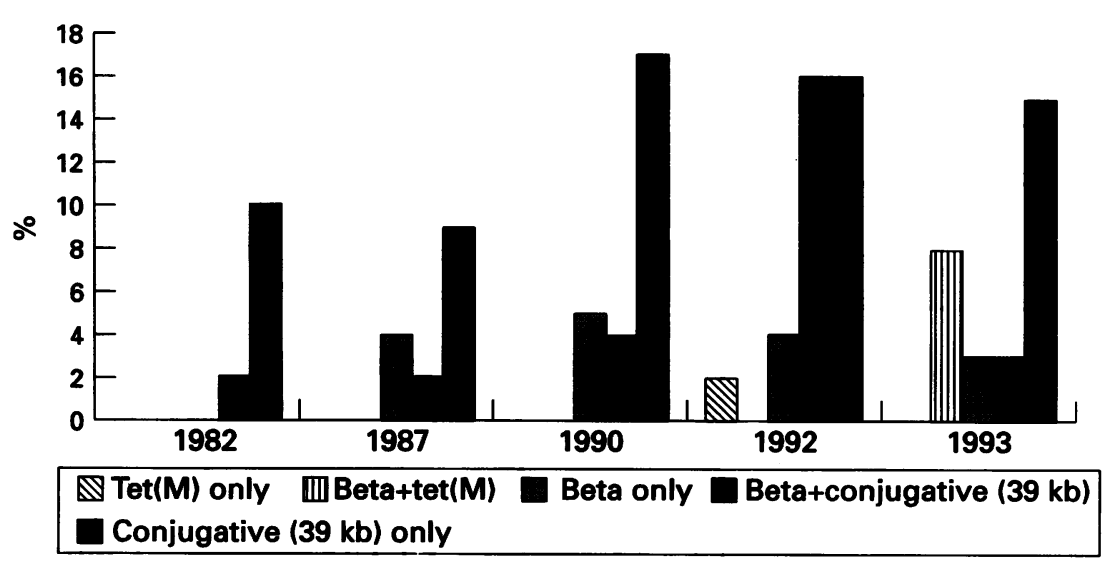

Percentage of $N$ gonorrhoeae strains with plasmids, the cryptic plasmid not accounted for.

\section{Results}

Chromosomally mediated resistance to ampicillins The distribution of MIC values of non-PPNG strains for ampicillin was similar for the time period 1982-1993 (table 2). In $19826 \%$ (6/104) of the non-PPNG strains had CMRA compared with $6 \%(2 / 34)$ in 1993. Eighty four percent (21/25) of all CMRA strains als 0 had CMRT.

Plasmid mediated resistance to ampicillin In all, 33 PPNG strains were found in the study. The proportion of PPNG strains rose during the period, with a peak in 1992 (tab) 2). In $1982,2 \%(2 / 106)$ of the strains wers PPNG and in $199313 \%(5 / 39)(p<0.02$. Beta-lactamase encoding plasmids of bot Asian and African types were found. The Asian type dominated in 1982 and 1987, buํㅛ in 1992 the African type was more frequent No other types of beta-lactamase encoding plasmids were found. The proportion of PPNG strains with the $39 \mathrm{~kb}$ conjugative plas: mid was high in 1992 (fig). Seven of these strains harboured the African plasmid and two of the strains harboured the Asian plas mid. The seven strains with African plasmids were of five different serovars. Five of the PPNG strains had a MIC value of $1.0 \mathrm{mg} / \mathrm{for}$ tetracycline, 25 PPNG strains had CMRT and three carried a tet $(M)$ plasmid. All strains which produced beta-lactamase according to the Nitrocefin test carried a beta-lactamase encoding plasmid.

Chromosomally mediated resistance to tetracycline The proportions of gonococcal strains with high MIC values to tetracycline increase during the study, especially during the latey part (table 2). In $198217 \%(18 / 106)$ of the isolates tested had CMRT compared wit $56 \%(20 / 36)$ of the non-tet(M) strains if 1993, $(p<0 \cdot 001)$. Eighteen percent (21/120 of all CMRT strains also had CMRA.

Plasmid mediated resistance to tetracycline A total of seven tet(M) containing gonococcal strains were found in the study. In April 1991 the first two strains with the tet(M) plasmid were isolated from a contact pair. The tet(M) 
plasmids were of the American type and the strains were of the serovar Arst. The strains also carried beta-lactamase plasmids of the African type. Another gonococcal strain with the same characteristics was isolated in June 1991. According to the patients the strains originated from Kenya, but there was no known contact between the first contact pair and the patient infected with the third isolate. The fourth tet $(\mathrm{M})$ strain of the serovar Arost was isolated in March 1992 and the fifth strain with the serovar Bpyvust in March 1993. These tet(M) plasmids were of the Dutch type, acquired in Brazil and Thailand. Another two tet(M) strains of Dutch type were isolated in September 1993 on the same occasion from the urethra of a man infected in Nigeria. These strains were of different serovars, Arost and Bpyvu, and carried different types of beta-lactamase encoding plasmids. The only tet( $\mathrm{M})$ strain lacking beta-lactamase plasmid had a MIC value of $1.0 \mathrm{mg} / \mathrm{l}$ to ampicillin.

\section{Other plasmids}

The $39 \mathrm{~kb}$ conjugative plasmid was found in $60 \%(18 / 30)$ of the non-tet(M) PPNG strains compared with $14 \%(52 / 370)$ of the nontet $(\mathrm{M})$ non-PPNG strains $(\mathrm{p}<0.001)$. The proportions of non-tet $(M)$ non-PPNG strains with the conjugative plasmid was almost doubled between 1987 and $1990(p<0.06, N S)$ (fig) and remained at the same level in 1992 and 1993. A total of 46/404 strains examined lacked the cryptic plasmid. Forty-one of them were plasmid free and five strains carried the conjugative plasmid only. The cryptic plasmid was more frequent in the later part of the study. Strains of the serovar Brpyust were common among strains without the cryptic plasmid. Sixteen of 35 isolated strains of this serovar lacked the cryptic plasmid ( $p<$ 0.001 ). These 16 strains did not harbour any plasmids.

\section{Serovars}

The 34 strains harbouring plasmids encoding for antibiotic resistance belonged to 18 different serovars. Four serovars were represented by three isolates, eight serovars were represented by two isolates and six serovars by one isolate. Strains belonging to the same serovar carried the same type of beta-lactamase and/or tet $(\mathrm{M})$ plasmid, except for the serovar Arst where two types of beta-lactamase plasmids were found in different isolates. It was noted that isolates of the same serovar could differ in the content of the conjugative plasmid.

\section{Discussion}

This is the first report of $N$ gonorrhoeae strains with tet(M) plasmids in Sweden. Increased proportions of $N$ gonorrhoeae strains with betalactamase plasmids and chromosomally mediated resistant to tetracycline were also found during 1982-1993. This increase is most likely due to importation from areas with high prevalence of antibiotic resistant gonococci.
In the later part of the present study the proportion of men increased. It has been shown that men more often have imported gonococcal infection than women..$^{22}$ The proportion of endemic gonococcal strains in Stockholm decreased by half to $40 \%$ during $1987-1989 .{ }^{23}$ In another study the majority of patients infected with PPNG strains of known origin were infected abroad, half of them in Asia. ${ }^{24}$ High prevalence of PPNG strains has been reported from Southeast Asia. ${ }^{25-27}$ Half of all tetracycline resistant $N$ gonorrhoeae strains isolated in Stockholm 1988 were imported from Asia $^{22}$ It has also been reported that a majority of the gonococcal strains isolated in both the Philippines and Thailand in 1989 and 1990 were resistant to tetracycline. ${ }^{2526}$ Tetracycline has never been a drug of choice for treating gonorrhoea in Sweden. However, resistance to tetracycline in $N$ gonorrhoeae strains might also arise in Sweden from treating presumed chlamydial infections and urethritis.

No alterations in the proportions of nonPPNG strains with chromosomally encoded resistance to ampicillin was found during 1982-1993. This stable situation is probably due to a limited pressure from treatment with ampicillin and the distribution has not changed in spite of the increased proportion of imported gonococcal strains. The choice of antibiotic treatment during the study depended on where the patient had contracted the infection. Ampicillin was the drug of choice for treating uncomplicated gonorrhoea in the beginning of this study period but spectinomycin was used if the patient was infected in Asia. During the later part of the study endemic gonorrhoea decreased as the treatment with ampicillin. The quinolones were used together with spectinomycin during the later part of the study since many patients were infected abroad. The evolution into the present level of ampicillin resistance took place some time between 1960 and 1982,28 most likely in the beginning of the $1960 \mathrm{~s}$ according to results from Denmark. ${ }^{11}$ The distribution of serovars among PPNG and/or tet(M) strains in the study implies a minor spread of those strains in Stockholm.

One third of the PPNG strains lacked the $39 \mathrm{~kb}$ conjugative plasmid or the tet $(\mathrm{M})$ plasmid. These gonococcal strains should not be able to transfer the beta-lactamase producing plasmid and consequently they will not contribute to the spread of this plasmid outside the clone. It has been shown in an in vitro experiment $^{29}$ that the transfer of the $39 \mathrm{~kb}$ conjugative plasmids were not as efficient as the transfer of beta-lactamase encoding plasmids. The proportion of gonococcal strains with $39 \mathrm{~kb}$ conjugative plasmid, but without the beta-lactamase encoding plasmid, has increased. Those strains are prepared to conjugate a beta-lactamase encoding plasmid. The frequency of the cryptic plasmid found in this study is in agreement with earlier findings. ${ }^{30}$ Gonococcal strains of the serovar Brpyust, lacking the cryptic plasmid, might have represented a clone in the beginning of the $1980 \mathrm{~s}$. 
The proportions of $N$ gonorrhoeae strains with chromosomally mediated resistance to tetracycline increased during the study. The proportion of PPNG strains increased as opposed to that of strains with chromosomally mediated resistance to ampicillin. This might imply that the proportion of gonococcal strains with tet $(\mathrm{M})$ plasmids will increase in Sweden in the future, as is the case in other countries. ${ }^{30}$ It emphasises the importance of the culturing of $N$ gonorrhoeae and the susceptibility testing of all gonococcal isolates. Ampicillin and tetracycline can not be recommended for treating gonorrhoea in Sweden.

Med lab technologist Lena Bengtsson and med lab technologist Margareta Reuter are thanked for skilful technical assistance. We thank ass prof Solgun Bygdeman and ass prof Eric Sandström for critical review of the manuscript. Ass prof Jon Jonasson is thanked for revising the English text. Ampicillin was kindly provided by Astra AB, Södertälje, Sweden and tetracycline by Pharmacia AB, Stockholm, Sweden.

1 Cannon JG, Sparling PF. The genetics of the gonococcus. Ann Rev Microbiol 1984;38:111-33.

2 Spratt BG. Resistance to $\beta$-lactam antibiotics mediated by alterations of penicillin-binding proteins. In: Bryan LE, ed. Microbial Resistance to Drugs. Springer-Verlag, Berlin 1989:77-100.

3 Franks AG. Successful combined treatment of penicillin resistant gonorrhea. Am ₹ Med Sci 1946;211:553-5.

4 Phillips I. $\beta$-lactamase-producing, penicillin-resistan gonococcus. Lancet 1976;2:656-7.

5 Ashford WA, Roman GG, Hemming VG. Penicillinaseproducing Neisseria gonorrhoeae. Lancet 1976;2:657-8.

6 Center for Disease Control. Penicillinase-producing Neisseria gonorrhoeae-United States, worldwide. Morbid Neisseria gonorrhoeae-United Sta
Mortal Weekly Rep 1979;28:85-7.

7 Bygdeman S, Kallings I, Danielsson D. Serogrouping and auxotyping for epidemiological study of $\beta$-lactamaseproducing Neisseria gonorrhoeae strains isolated in Sweden. Acta Dermatovenereol (Stockh) 1981;61:329-34

8 Bergström S, Norlander L, Norqvist A, Normark S Contribution of a TEM-1-like beta-lactamase to penicillin resistance in Neisseria gonorrhoeae. Antimicrob Agents Chemother 1978;13:618-23.

9 Roberts MC. Plasmids of Neisseria gonorrhoeae and other Neisseria species. Clin Microbiol Rev 1989;2:18-23.

10 Chopra I, Hawkey PM, Hinton M. Tetracyclines, molecular and clinical aspects. F Antimicrob Chemother 1992; 29:245-77.

11 Reyn A, Korner B, Weis Bentzon M. Effects of penicillin streptomycin, and tetracycline on $N$ gonorrhoeae isolated in 1944 and in 1957. Br F Venereal Dis 1958;34:227-39.

12 Center for Disease Control. Tetracycline-resistant Neisseria gonorrhoea-Georgia, Pennsylvania, New Hampshire. Morbid Mortal Weekly Rep 1985;34:563-70.
13 Morse SA, Johnson SR, Biddle JW, Roberts MC. Highlevel tetracycline resistance in Neisseria gonorrhoeae is result of acquisition of streptococcal tet $\mathrm{M}$ determinant. Antimicrob Agents Chemother 1986;30:664-70.

14 Burdett V. Streptococcal tetracycline resistance mediated at the level of protein synthesis. $\mathcal{F}$ Bacteriol 1986;165: $564-9$

15 Gascoyne DM, Heritage J, Hawkey PM, Turner A, van Klingeren B. Molecular evolution of tetracyclineresistance plasmids carrying TetM found in Neisseria gonorrhoeae from different countries. $f$ Antimicrob Chemother 1991;28:173-83.

16 Gascoyne-Binzi DM, Heritage J, Hawkey PM. Nucleotide sequences of the tet $(\mathrm{M})$ genes from the American and Dutch type tetracycline resistance plasmids of Neisseria gonorrhoeae. F Antimicrobial Chemother 1993;32:667-76.

17 Roberts MC, Knapp JS. Transfer of $\beta$-lactamase plasmids from Neisseria gonorrhoeae to Neisseria meningitidis and commensal Neisseria species by the $25 \cdot 2$-megadalton conjugative plasmid. Antimicrob Agents and Chemother conjugative plas

18 Ringertz S, Rylander M, Kronvall G. Disk diffusion method for susceptibility testing of Neisseria gonorrhoeae. method for susceptibility testing

19 Extraction and purification of plasmid DNA. In: Sambrook J, Fritsch EF, Maniatis T, eds. Molecular Cloning: A Laboratory Manual. Second edition. Cold Spring Harbor Laboratory, Cold Spring Harbor, New York, 1989.

20 Macrina FL, Kopecko DJ, Jones KR, Ayers DJ, McCowen SM. A multiple plasmid-containing Escherichia coli strain: convenient source of size reference plasmid molecules. Plasmid 1978;1:417-20.

21 Bäckman M, Rudén A-KM, Bygdeman SM, Jonsson A, Ringertz O, Sandström EG. Gonococcal serovar distribution in Stockholm, with special reference to multiple ution in Stockholm, with special reference to multiple infections and infected partners. Acta

22 Bygdeman SM, Rudén A-K, Jonsson A, et al. Antibiotic susceptibility, serovars and auxotypes of gonococcal isolates in Stockholm. Relation to geographical origin of the infection. Int ₹ STD AIDS 1993;4:33-40.

23 Rudén A-K, Jonsson A, Lidbrink $P$, Allebeck $P$, Bygdeman SM. Endemic versus non-endemic gonorthoea in Stockholm: results of contact tracing. Int $尹$ STD AIDS 1993;4:284-92.

24 Rudén A-K. Temporal changes in the gonococcal serovar patterns in Stockholm during two years with special patterns in Stockholm during two years with special 256-61.

25 Clendennen III TE, Hames CS, Kees ES, et al. In vitro antibiotic susceptibilities of Neisseria gonorrhoeae isolates in the Philippines. Antimicrob Agents Chemother 1992;36: 277-82.

26 Clendennen TE, Echeverria P, Saengeur S, Kees ES, Boslego JW, Wignall FS. Antibiotic susceptibility survey of Neisseria gonorrhoeae in Thailand. Antimicrob Agents Chemother 1992;36:1682-7.

27 Kam K-M, Lai C-F, Egglestone S, Chan C-BB. Patterns of antibiotic susceptibility of gonococci isolated in Hong Kong, 1987-1990. Sex Transm Dis 1992;19:284-7.

28 Ringertz $\mathrm{O}$. The sensitivity of $N$ gonorrhoeae to antibiotics. Acta Pathol Microbiol Scand 1961;53:173-9.

29 Roberts M, Falkow S. Plasmid-mediated chromosomal gene transfer in Neisseria gonorrhoeae. $\mathcal{F}$ Bacteriol 1978; 134:66-70

30 Roberts M, Piot P, Falkow S. The ecology of gonococcal plasmids. F Gen Microbiol 1979;114:491-4. 